\title{
PENERAPAN MODEL INKUIRI TERBIMBING PADA MATERI GERAK HARMONIK SEDERHANA DI KELAS XI IPA MAN SANGGAU LEDO
}

\author{
Eka Trisianawati, SP, M.Pd ${ }^{1)}$, Dwi Fajar Saputra ${ }^{2)}$, Ummi Munawaroh ${ }^{3)}$ \\ 1) Program Studi Pendidikan Fisika, Fakultas Pendidikan MIPA dan Teknologi IKIP PGRI Pontianak, Jalan Ampera No.88 \\ Pontianak \\ E-mail: trisianawatieka@gmail.com
}
2) Program Studi Pendidikan Fisika Fakultas Pendidikan MIPA dan Teknologi IKIP PGRI Pontianak, Jalan Ampera No.88 Pontianak
E-mail:dwifajar24@gmail.com
3) Program Studi Pendidikan Fisika Fakultas Pendidikan MIPA dan Teknologi IKIP PGRI Pontianak, Jalan Ampera No.88 Pontianak
E-mail: ummimunawaroh@yahoo.com

\begin{abstract}
Abstrak. Penerapan Model Inkuiri Terbimbing Pada Materi Gerak Harmonik Sederhana Di Kelas XI IPA MAN Sanggau Ledo. Berdasarkan hasil wawancara yang dilakukan dengan guru bidang studi fisika di MAN Sanggau Ledo, bahwa guru dalam mengajar masih menggunakan metode tradisional, yaitu metode ceramah. Salah satunya materi gerak harmonik sederhana dan hasil belajar siswa pada materi gerak harmonik sederhana di kelas XI IPA MAN Sanggau Ledo rendah yang kurang dari nilai KKM yaitu 70. Hal ini dibuktikan dari hasil ulangan siswa yang tuntas sebanyak $26,32 \%$ dan yang tidak tuntas sebanyak 73,69\%, yang keseluruhan jumlah siswa 19 orang di kelas XI IPA MAN Sanggau Ledo Tahun Ajaran 2014/2015 semester ganjil,dan berdasarkan wawancara dengan guru bidang studi yang ada disekolah tersebut belum pernah menerapkan model inkuiri terbimbing. Adapun tujuan khusus dalam penelitian ini adalah (1) Untuk mengetahui hasil belajar siswa sebelum diajarkan dengan model inkuiri terbimbing pada materi gerak harmonik sederhana di kelas XI IPA MAN Sanggau Ledo. (2) Untuk mengetahui hasil belajar siswa setelah diajarkan dengan model inkuiri terbimbing pada materi gerak harmonik sederhana di kelas XI IPA MAN Sanggau Ledo. (3) Untuk mengetahui peningkatan hasil belajar siswa setelah diajarkan dengan model inkuiri terbimbing pada materi gerak harmonik sederhana di kelas XI IPA MAN Sanggau Ledo. Metode yang digunakan dalam penelitian ini adalah penelitian exsperimen, bentuk penelitian yang digunakan dalam penelitian ini adalah pre-experimental design, dan rancangan yang digunakan dalam penelitian ini adalah one-group pre-test post-test design. Populasi dalam penelitaian ini siswa kelas XI IPA MAN Sanggau Ledo, dan dalam penelitian ini pengambilan sampel dilakukan menggunakan nonprobability sampling, teknik yang digunakan adalah sampling jenuh. Alat pengumpul data yang digunakan dalam penelitian ini adalah tes berbentuk essay. Berdasarkan analisis data disimpulkan bahwa: (1) Hasil belajar siswa sebelum diajarkan dengan pembelajaran model inkuiri terbimbing pada materi gerak harmonik sederhana memiliki rata-rata nilai 36.82 yang tergolong rendah dengan standar deviasi 9.48. (2) Hasil belajar siswa setelah diajarkan dengan pembelajaran model inkuiri terbimbing pada materi gerak harmonik sederhana memiliki rata-rata nilai 65.45 yang tergolong cukup dengan standar deviasi 9.47. (3) Dari hasil uji hipotesis dengan menggunakan uji-t, pada taraf signifikansi 5\% diperoleh $t$ hitung > t tabel atau $4.58>2.079$, maka Ha diterima. Dengan demikian pembelajaran menggunakan model inkuiri terbimbing pada materi gerak harmonik sederhana terdapat peningkatkan hasil belajar siswa.
\end{abstract}

Kata Kunci: Inkuiri Terbimbing, Gerak Harmonik Sederhana

\section{PENDAHULUAN}

Fisika merupakan bagian dari IPA (Ilmu Pengetahuan Alam) atau sains, sains berkaitan dengan cara mencari tahu tentang alam secara sistematis berupa penemuan, fakta, konsep-konsep atau prinsip-prinsip serta prospek pengembangan lebih lanjut dalam menerapkan pengetahuan di dalam kehidupan sehari-hari [1]. Tujuan pembelajaran fisika SMA sebagai bagian dari IPA adalah agar siswa dapat memahami konsep-konsep fisika dan mampu menggunakan metode ilmiah yang didasari oleh sikap ilmiah untuk memecahkan masalah yang dihadapinya [2]. Jadi 


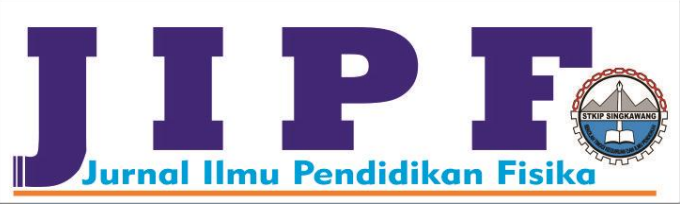

pembelajaran fisika yang diharapkan berlangsung di sekolah adalah pembelajaran yang sesuai dengan tujuan pembelajaran fisika itu sendiri yakni berlangsungnya pembelajaran yang didasarkan pada prinsip-prinsip ilmiah baik sikap ilmiah, proses ilmiah maupun produk ilmiah.

Berdasarkan hasil wawancara (10 April 2015) di MAN Sanggau Ledo dengan guru matapelajaran fisika, bahwa guru dalam mengajar masih menggunakan metode tradisional, yaitu dengan metode ceramah. Salah satunya yaitu pada materi gerak harmonik sederhana umumnya masih menekankan aspek kognitif. Kegiatan hafalan mendominasi untuk menguasai ilmu pengetahuan, dengan tidak mengembangkan sikap ilmiah dan keterampilan berpikir yang dapat memberikan pengalaman nyata dan eksperimen aktif.

Pengetahuan yang diperoleh peserta didik dalam pembelajaran fisika di kelas XI IPA MAN Sanggau Ledo sangatlah terbatas disebabkan guru tidak pernah memberikan praktikum dikarenakan alat-alat praktikum tidak memadai, untuk itu guru perlu memperluas pengetahuan ini dengan penalaran peserta didik melalui menemukan sendiri hal-hal baru dalam bentuk pengalaman belajar yang bermakna sehingga dapat meningkatkan hasil belajar siswa. Salah satunya pada materi pembelajaran fisika yaitu gerak harmonik sederhana. Gerak harmonik merupakan salah satu materi pembelajaran fisika di kelas XI IPA MAN Sanggau Ledo semester 1 yang menekankan pada pengetahuan, keterampilan dan sikap, yang harus dipelajari oleh peserta didik dalam rangka mencapai standar kompetensi yang telah ditentukan, namun pada kenyataannya nilai hasil belajar siswa pada materi ini rendah yang kurang dari nilai KKM yaitu 70. Hal ini dibuktikan dari hasil ulangan siswa yang tuntas sebanyak $26,32 \%$ dan yang tidak tuntas sebanyak $73,69 \%$, yang keseluruhannya jumlah siswa 19 orang di kelas XI IPA MAN Sanggau ledo Tahun Ajaran 2014/2015 semester ganjil.

Cara mengatasi hasil belajar siswa yang rendah pada materi gerak harmonik sederhana di kelas XI IPA MAN Sanggau Ledo di semester ganjil peneliti menerapkan model inkuiri. Karena model inkuiri merupakan pembelajaran yang mempersiapkan situasi bagi siswa untuk
Jurnal Ilmu Pendidikan Fisika

Volum 1 Nomor 1 Maret 2016. Halaman 23-28 p-ISSN: 2477-5959 e-ISSN: 2477-8451

melakukan eksperimen sendiri; dalam arti luas ingin melihat sesuatu yang terjadi, ingin melakukan sesuatu, ingin menggunakan simbolsimbol dan mencari jawaban atas pertanyaan sendiri, menghubungkan penemuan yang satu yang lain, serta membandingkan sesuatu yang ditemukan oleh diri sendiri dengan yang ditemukan orang lain [3]. Inkuiri terbagi menjadi 3 jenis yaitu inkuiri terbimbing, inkuiri bebas, dan inkuiri bebas yang dimodifikasi. Dari ketiga jenis model inkuiri tersebut peneliti memilih inkuiri terbimbing, karena dari hasil wawancara bahwa guru MAN Sanggau Ledo belum pernah menggunakan model inkuiri. Sedangkan model inkuiri terbimbing digunakan bagi siswa yang kurang berpengalaman belajar dengan menggunakan model inkuiri. Dengan model ini, siswa belajar lebih berorientasi kepada bimbingan dan petunjuk dari guru, sehingga ia mampu memahami konsep-konsep pelajaran. Pembelajaran model inkuiri terbimbing diterapkan agar para peserta didik bebas mengembangkan konsep yang mereka pelajari dan mereka diberi kesempatan untuk memecahkan masalah yang mereka hadapi secara berkelompok, berinteraksi sosial dengan kawan sebayanya untuk saling bertukar informasi antar kelompok [4].

Melalui model inkuiri terbimbing, siswa lebih mudah memahami materi tersebut, sehingga dapat meningkatkan hasil belajar siswa. Dengan demikian, model inkuiri terbimbing cocok dengan materi gerak harmonik sederhana karena dapat mengatasi kesulitan belajar siswa dengan cara siswa dilibatkan langsung secara maksimal seluruh kemampuan siswa untuk mencari dan menyelidiki secara sistematis, kritis, logis, dan analitis, sehingga dapat merumuskan sendiri penemuannya dengan penuh percaya diri melalui kegiatan percobaan atau praktikum..

\section{METODE}

Metode yang digunakan dalam penelitian ini adalah penelitian exsperimen, bentuk penelitian yang digunakan dalam penelitian ini adalah preexperimental design, dan rancangan yang digunakan dalam penelitian ini adalah one-group pre-test post-test design. Populasi dalam penelitaian ini siswa kelas XI IPA MAN Sanggau 


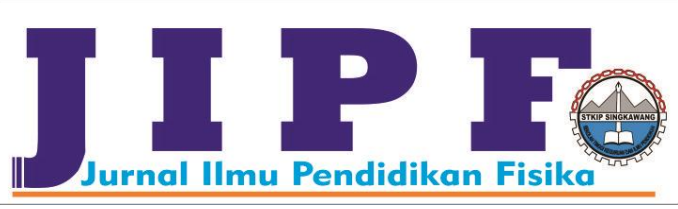

Ledo, dan dalam penelitian ini pengambilan sampel dilakukan menggunakan nonprobability sampling, teknik yang digunakan adalah sampling jenuh, teknik ini digunakan karena jumlah populasi relative kecil. Instrumen yang digunakan adalah tes hasil belajar berbentuk soal essay sebanyak 8 soal yang telah diujicobakan. Berdasarkan dari hasil pengolahan data dengan jumlah siswa 22 siswa maka diperoleh nilai pretes tertinggi 50 dan nilai terendah 20 dengan rata-rata 36.82. Sedangkan hasil posttest diperoleh nilai tertinggi 80 dan nilai terendah 50 dengan rata-rata 65.45. Dilihat dari hasil rekapitulasi nilai pre-test dan rekapitulasi nilai post-test terdapat peningkatan keduanya. Dengan demikian pembelajaran menggunakan model inkuiri terbimbing pada materi gerak harmonik sederhana terdapat peningkatkan hasil belajar siswa.

\section{HASIL DAN PEMBAHASAN}

Data yang diperoleh dalam penelitian ini adalah data yang terkumpul dari tes yang diberikan kepada siswa/siswi MAN Sanggau Ledo berupa pretest dan posttest yang diberikan pada satu kelas yaitu kelas XI IPA.

TABEL 1

REKAPITUlasi HASIL PRE-TEST DAN POST-TEST SiSWA

\begin{tabular}{ccc}
\hline & Nilai Pre-Test & Nilai Post-Test \\
\hline Jumlah siswa & 22 & 22 \\
Nilai Minimum & 20 & 50 \\
Nilai Maksimum & 50 & 80 \\
Nilai Rata-rata & 36,82 & 65,45 \\
Standar Deviasi & 9.48 & 9.47
\end{tabular}

Tes hasil belajar sebelum (pretest) pembelajaran bertujuan untuk mengetahui kemampuan dasar yang dimiliki oleh masing-masing siswa. Hasil data menunjukan bahwa sebelum pembelajaran rata-rata hasil tes siswa yang diperoleh tergolong rendah, dapat dijelaskan bahwa nilai rata-rata tes awal adalah sebesar 36.82 dan standar deviasi tes awal adalah 9.48. Rendahnya hasil tes sebelum pembelajaran ini disebabkan karena siswa kurang menguasai materi gerak harmonik sederhana pada indikator menjelaskan gerak pada gerak getaran, menjelaskan faktor-faktor yang mempengaruhi periode getaran, menentukan besar gaya simpangan pada gerak getaran, menentukan besar
Jurnal Ilmu Pendidikan Fisika

Volum 1 Nomor 1 Maret 2016. Halaman 23-28 p-ISSN: 2477-5959 e-ISSN: 2477-8451

kecepatan pada gerak getaran dan menentukan besar percepatan pada gerak getaran.

Dari analisis data posttest dapat diketahui bahwa siswa mengalami tingkat ketuntasan yang maksimal, nilai rata-rata tes akhir siswa yaitu 65,45 . Hasil penelitian ini menunjukan bahwa penerapan menggunakan model inkuiri terbimbing dapat meningkatkan hasil belajar siswa pada materi gerak harmonik sederhana di kelas XI IPA MAN Sanggau Ledo. Meningkatnya hasil belajar siswa sesudah di terapkan menggunakan model inkuiri terbimbing karena pembelajaran menggunakan model inkuiri terbimbing dapat membantu siswa lebih aktif dan siswa dapat lebih memahami materi gerak harmonik sederhana melalui percobaan yang mereka lakukan sendiri.

\section{A. Hasil Uji Normalitas}

\section{Hasil Uji Normalitas Pretest}

Pengujian normalitas dilakukan dengan maksud untuk mengetahui apakah data berdistribusi normal atau tidak. Pengujian normalitas dilakukan dengan menggunakan statistik liliefors Berdasarkan hasil pengujian normalitas pretest maka diperoleh $\mathrm{L}$ hitung $=0.0823$ dan $\mathrm{L}$ tabel $=$ 0.1832 yang dapat dilihat pada Tabel 2 .

TABEL 2

HASIL PERHITUNGAN UJI NORMALITAS PRETEST

\begin{tabular}{cc}
\hline L hitung & 0,823 \\
\hline L tabel & 0,1832 \\
\hline Keterangan & Normal \\
\hline
\end{tabular}

Nilai $L$ tabel diambil berdasarkan nilai pada tabel liliefors pada taraf signifikansi 5\% kriteria dibuat berdasarkan pada ketentuan pengujian hipotesis normalitas yaitu Jika $L$ hitung $<L$ tabel, maka populasi berdistribusi normal dan jika L hitung $\geq L$ tabel, maka populasi tidak berdistribusi normal. Pada tabel 4.2 tersebut terlihat bahwa nilai $L$ hitung lebih kecil dari nilai $L$ tabel maka dinyatakan data berdistribusi normal

\section{Hasil Uji Normalitas Posttest}

Pengujian normalitas dilakukan dengan maksud untuk mengetahui apakah data berdistribusi normal atau tidak. Pengujian normalitas dilakukan dengan menggunakan uji liliefors Berdasarkan hasil pengujian normalitas posttest maka diperoleh 


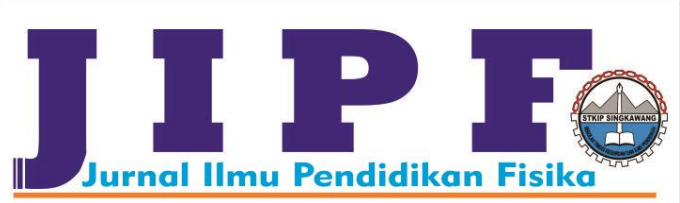

$\mathrm{L}$ hitung $=0.135 \quad$ dan $L$ tabel $=0.1832$ yang dapat dilihat pada Tabel 3.

TABEL 3

HASIL PERHITUNGAN UJI NORMALITAS POSTTEST

\begin{tabular}{cc}
\hline L hitung & 0,135 \\
\hline L tabel & 0,1832 \\
\hline Keterangan & Normal \\
\hline
\end{tabular}

Nilai L tabel diambil berdasarkan nilai pada tabel liliefors pada taraf signifikansi 5\% kriteria dibuat berdasarkan pada ketentuan pengujian hipotesis normalitas yaitu Jika $L$ hitung $<L$ tabel, maka populasi berdistribusi normal dan jika Lhitung $\geq$ Ltabel, maka populasi tidak berdistribusi normal. Pada Tabel 3 tersebut terlihat bahwa nilai $L$ hitung lebih kecil dari nilai $L$ tabel maka dinyatakan data berdistribusi normal.

\section{B. Hasil Pengujian Hipotesis}

Setelah dilakukan uji normalitas dan hasil data berdistribusi normal, kemudian dilakukan pengujian hipotesis dengan menggunakan uji- $t$ dengan kriteria: Jika $t_{\text {hitung }}>t_{\text {tabel }}$, maka $H_{a}$ diterima dan jiika $t_{\text {hitung }}<t_{\text {tabel }}$, maka $H_{a}$ ditolak. Adapun hasil perhitungan uji-t dapat dilhat pada Tabel 4.

TABLE 4

HASIL UJI-T

\begin{tabular}{cc}
\hline t hitung & 4,58 \\
\hline $\mathrm{t}$ tabel $(\mathrm{db}=21, \alpha=0,05)$ & 2,079 \\
\hline kesimpulan & Ha diterima \\
\hline
\end{tabular}

Dari hasil perhitungan diperoleh t_hitung> t_tabel, maka H_a diterima.

$\mathrm{H} \_\mathrm{a}=$ terdapat peningkatan hasil belajar siswa setelah diajarkan dengan model inkuiri terbimbing pada materi gerak harmonik sederhana dikelas XI IPA MAN Sanggau Ledo.

Tujuan dari penelitian ini adalah untuk mengetahui penerapan model inkuiri terbimbing pada materi gerak harmonik sederhana di kelas XI IPA MAN Sanggau Ledo. Pembelajaran inkuiri terbimbing merupakan pembelajaran yang secara langsung melibatkan siswa dalam menemukan konsep-konsep tertentu dari sebuah teori suatu pembelajaran. Pada saat itu keterlibatan guru hanya sebagai pembimbing siswa dalam
Jurnal Ilmu Pendidikan Fisika

Volum 1 Nomor 1 Maret 2016. Halaman 23-28 p-ISSN: 2477-5959 e-ISSN: 2477-8451

menemukan konsep tersebut agar tidak menyimpang dari konsep yang ingin ditemukan. Menurut [4] bahwa, model inkuiri terbimbing adalah model pembelajaran yang didalamnya terdapat beberapa kegiatan yang bersifat ilmiah, peserta didik menyampaikan ide-ide sebelum topik tersebut dipelajari, peserta didik menyelidiki sebuah gejala atau fenomena, peserta didik menjelaskan fakta-fakta dan membandingkannya secara saintifik. Dengan demikian inkuiri terbimbing memberikan kesempatan kepada peserta didik untuk bekerja merumuskan prosedur, menganalisis hasil dan mengambil kesimpulan secara mandiri.

Pada awal pembelajaran guru memberikan orientasi, orientasi ini merupakan langkah yang dilakukan guru untuk mengkondisikan peserta didik agar siap melaksanakan proses pembelajaran. Dalam kegiatan ini guru menyajikan suatu cerita sehingga menimbulkan suatu masalah yang dapat memotivasi siswa untuk siap belajar dan mempunyai rasa keingintahuan, kemudian guru menjelaskan tujuan pembelajaran yang ingin dicapai. Pada awal pembelajaran guru membagi siswa dalam 4 kelompok yang terdiri dari 5-6 orang siswa, setelah itu guru membagikan LKS dan alat praktikum pada setiap kelompok.

Tahap selanjutnya adalah kegiatan inti, terdapat lima fase kegiatan inti dalam pembelajaran model inkuiri terbimbing yaitu mengidentifikasi masalah, merumuskan hipotesis, melakukan percobaan dan mengumpukan data, analisis data, dan membuat kesimpulan [5]. Fase pertama mengidentifikasi masalah yaitu guru membimbing siswa kedalam permasalahan yang terkait dengan materi yang disampaikan. Rumusan masalah ini sudah terdapat pada LKS kigatan siswa hanya membaca dan memahami. Model pembelajaran inkuiri terbimbing mempunyai ciri-ciri yaitu siswa melakukan identifikasi masalah yang berdasarkan penyelidikan atau pengamatan [6].

Fase kedua yaitu merumuskan hipotesis, hipotesis merupakan jawaban sementara dari suatu permasalahan. Pada fase ini guru membimbing siswa untuk merumuskan hipotesis terhadap rumusan masalah dari LKS. Fase ketiga yaitu mengumpulkan data, pada fase ini merupakan aktivitas menjaring informasi yang dibutuhkan 


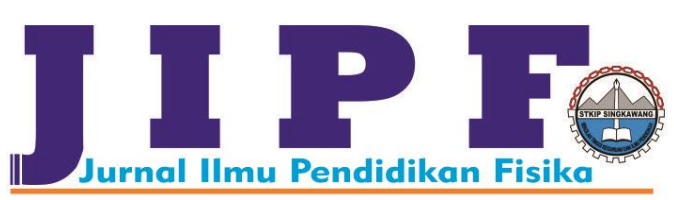

untuk menguji hipotesis yang diajukan. Dalam inkuiri terbimbing menjaring informasi dilakukan bersama-sama antara guru dan peserta didik. Guru membimbing siswa untuk melakukan percobaan dan mengisi data, guru membimbing siswa dan mengarahkan pertanyaan-pertanyaan kepada siswa kedalam langkah-langkah percobaan yang terdapat pada LKS dan membimbing siswa mengamati perubahan yang terjadi. Setelah itu siswa melakukan percobaan, siswa melakukan pengisian data. Siswa melakukan pengamatan dengan cermat dan teliti agar hasil yang diperoleh sesuai dengan teori. Dalam percobaan siswa mengumpulkan data yang didapat dari hasil percobaan. Dalam percobaan siswa dapat berinteraksi dan bekerjasama sesama anggota kelompok. Ada beberapa prinsip dalam penggunaan model inkuiri terbimbing yaitu prinsip interaksi, prinsip bertanya, prinsip belajar untuk berfikir, dan prisip keterbukaan [7]. Dengan menggunakan inkuiri terbimbing dapat memperkuat dan menambah kepercayaan pada diri sendiri dengan proses menemukan sendiri karena pembelajaran berpusat pada siswa dengan peran guru yang terbatas.

Fase keempat yaitu menganalisis data berdasarkan data yang ditemukan. Siswa menganalisis data hasil percobaan, membandingkan data yang ada untuk membuktikan kebenaran hipotesis yang siswa buat. Guru membimbing siswa menganalisis data, pada fase ini siswa sering mengajukan pertanyaan, dikarena mereka ada yang belum memahami. Fase terakhir yaitu merumuskan kesimpulan, merumuskan kesimpulan merupakan proses mendiskripsikan temuan yang diperoleh berdasarkan hasil percobaan. Pada fase ini siswa menyimpulkan hasil percobaan, dan hasil simpulan yang dibuat siswa menunjukkan bahwa siswa mampu melakukan "trial dan eror" atau bersepekulasi berbagai cara untuk memecahkan masalah dan kesulitan. Siswa melakukan "trial dan eror" atau bersepekulasi berbagai cara untuk memecahkan masalah dan kesulitan [7]. Kegiatan penutup dalam pembelajaran ini berupa guru meminta hasil percobaan berupa LKS dan memberi salam.
Jurnal Ilmu Pendidikan Fisika

Volum 1 Nomor 1 Maret 2016. Halaman 23-28 p-ISSN: 2477-5959 e-ISSN: 2477-8451

\section{IV.SIMPULAN DAN SARAN}

\section{A. Simpulan}

Berdasarkan hasil pengolahan data, secara umum dapat disimpulkan bahwa pembelajaran model inkuiri terbimbing pada materi gerak harmonik sederhana dikelas XI IPA MAN Sanggau Ledo lebih baik. Sejalan dengan rumusan masalah penelitian, secara khusus dapat disimpulkan:

1. Hasil belajar siswa sebelum diajarkan dengan pembelajaran model inkuiri terbimbing pada materi gerak harmonik sederhana memiliki ratarata nilai 36.82 yang tergolong rendah dengan standar deviasi 9.48 .

2. Hasil belajar siswa setelah diajarkan dengan pembelajaran model inkuiri terbimbing pada materi gerak harmonik sederhana memiliki ratarata nilai 65.45 yang tergolong cukup dengan standar deviasi 9.47.

Dari hasil uji hipotesis dengan menggunakan uji- $t$, pada taraf signifikansi $5 \%$ diperoleh $t$ hitung $>\mathrm{t}$ tabel atau $4.58>2.079$, maka $\mathrm{Ha}$ diterima. Dengan demikian pembelajaran menggunakan model inkuiri terbimbing pada materi gerak harmonik sederhana terdapat peningkatkan hasil belajar siswa.

\section{B. Saran}

Beberapa saran yang dapat disampaikan berdasarkan hasil penelitian ini adalah:

1) Diharapkan agar dapat mengatur alokasi waktu seefesien munkin untuk kegiatan pembelajaran sehingga penerapan model inkuiri terbimbing berjalan optimal dan sesuai dengan tujuan yang ingin dicapai dalam kegiatan pembelajaran.

2) Diharapkan sebelum memberikan perlakuan alat dan bahan percobaan disiapkan, agar tidak terjadi pergantian alat dalam setiap kelompok siswa.

3) Disarankan bagi peneliti yang ingin menggunakan pembelajaran dengan model inkuiri terbimbing untuk lebih menguasai kelas sebaik mungkin, sehingga dapat memberikan motivasi kepada siswa agar dapat berperan aktif dalam pelaksanaan pembelajaran.

4) Diharapkan kepada peneliti selanjutnya untuk berusaha melakukan penelitian lanjutan dengan menyempurnakan kekurangan- 
kekurangan yang terdapat pada sekripsi ini, karena penelitian ini masih jauh dari kesempurnaan.

5) Analisis instrumen dalam penelitian ini sangat lemah sekali, jadi masih perlu diuji cobakan ulang instrumen untuk penelitian selanjutnya.

\section{DAFTAR PUSTAKA}

[1] Priandono E.F, Astutik S, Wahyuni S. 2012. "Pengembangan Media Audio-Visual Berbasis Kontekstual Dalam Pembelajaran Fisika Di SMA". Jurnal Pembelajaran Fisika. ISSN:2301-9794. Vol 1, No 3.

[2] Sudarmini Y, dkk. (2015). "Pembelajaran Fisika Berbasis Inkuiri Terbimbing Dengan Menggunakan LKS Untuk Meningkatkan Keterampilan Berpikir Kritis Ditinjau Dari Sikap Ilmiah Siswa Madrasah Aliyah Qamarul Huda Bagu Lombok Tengah”. Jurnal Penelitian Pendidikan IPA (JPPIPA), ISSn 2407-795X. vol 1, No 1.

[3] Putra, R.S. (2012). Desain Belajar Mengajar Kreatif Berbasis Sains. Jember: Diva Press

[4] Chodijah, S., Fauzi, A. \& Wulan, R. 2012.Pengembangan Perangkat Pembelajaran Fisika Menggunakan Model Guided Inquiry yang dilengkapi Penilaian Portofolio pada Materi Gerak Melingkar. Jurnal Penelitian Pembelajaran Fisika Universitas Negeri Padang. Vol 1, No. 1, Hal 1-19, ISSN: 2252-3014.

[5] Sendy Zulia Witanecahya, Budi Jatmiko. 2014. Penerapan Model Pembelajaran Inkuiri Terbimbing (Guided Inquiry) untuk Mengurangi Miskonsepsi Siswa Kelas X SMAN 2 Ponorogo pada Pokok Bahasan Perpindahan Panas. Jurnal Inovasi Pendidikan Fisika (JIPF) Vol. 03 No. 03 Tahun 2014, Hal 6-10, ISSN: 2302-4496.

[6] M. Yasin Kholifudin. 2012. Pembelajaran Fisika dengan Inkuiri Terbimbing Melalui MetodeEksperimen dan Demonstrasi Ditinjau dari Gaya Belajar Siswa. Prosiding Pertemuan Ilmiah XXVI HFI Jateng \& DIY, Purworejo, ISSN : 0853-0823.

[7] Zuldafrial. 2009. "Belajar Interaksi Belajar Mengajar". Pontianak: STAIN Press Pontianak. 